\title{
Original Article Effect of Membrane Sweeping on Induction of Labour a Randomized Controlled Trial
}

N.E.Ashmawy, T.M.Assar, S.M.Taha and E.A.Helmy

Obstetrics and Gynecology., Faculty of Medicine, Benha Univ., Benha, Egypt

E-Mail:emam@gmail.com

\begin{abstract}
Membrane sweeping may increase chances of labour starting naturally within 48 hours of the procedure. Prostaglandins appears to be as effective an induction agent in the third trimester. This study aimed to assess the effect of membranes sweeping on induction of labour at full-term from $39 \frac{1}{7}$ to $40 \frac{6}{7}$ weeks. This study was randomized controlled study which done at Benha University Clinic Also Benha showing healing center. Person handrad and twenty instances were recruited around the individuals going to obstetrics \& Gynecology offices from claiming both healing facilities require for incitement of Labor toward full term. Members were haphazardly planned under two groups: aggregation An film clearing (60 patients) that were subdivided under A1: Primigravida (30 patients) Furthermore A2: Multigravida (30 patients). Gathering $b$ no film clearing (60 patients) subdivided under B1 Primigravida (30 patients) Also B2 Multigravida (30 patients). Situations for aggregation a were under went film clearing In full term starting with 39 will 40 weeks. Instances done gathering $\mathrm{b}$ who were under went incitement from claiming Labor Toward intra vaginal misoprostol $25 \mu \mathrm{g}$ 4-hourly on An most extreme 4 doses. There were no statistically huge distinction between gathering a and one assembly $b$ in regards to Age, GA, mode of delivery, diocesan Score, cervical length Also Partogram exceptional indications. There might have been statistically critical diminish Previously, Interrval between manet /Labour "around assembly A1 over one assembly B1. There might have been statistically critical decline On Interrval the middle of manet/Labour "around aggregation A2 over gathering B2. Triumph rate for film clearing "around aggregation a might have been $81.7 \%$. There might have been no statistically critical Contrast between one assembly A1 and bunch A2 in regards victory rate of film clearing. Clearing for membranes may be An safe strategy to diminishing those period for term pregnancy and the frequency about prolonged gestation for An low danger number. There is no confirmation that clearing those membranes expands those danger for maternal and neonatal unfriendly conclusions.
\end{abstract}

Key words: Membrane Sweeping, Induction of Labour, Vaginal misoprostol.

\section{Introduction}

To About 30 years, the worldwide health awareness group keeping need acknowledged the perfect gas rate to cesarean segments with a chance to be between $10 \%$ and $15 \%$. From that point forward cesarean segments need get to be progressively as a relatable point done both produced Furthermore creating nations to an assortment of reasons. [1]. Those impacts about cesarean segment rates on other outcomes, for example, maternal Furthermore perinatal morbidity, pediatric outcomes, What's more mental or social prosperity would still vague. A greater amount Examine will be necessary on see the wellbeing impacts for cesarean segment ahead prompt and future results. [2]. Incitement from claiming Labor may be an mediation that abatements the hazard for difficulties Also cesarean segment. Incitement of Labor will make advertised toward haul. There would a few distinctive routines for incitement. One or every last bit about them might make advertised reliant on distinctive condition. [3]. Film clearing might expansion possibilities from claiming work beginning characteristically inside 48 hours of the system. Film sweeps will be advertised at 41 weeks. This includes endeavor An vaginal examination et cetera putting a finger inside the cervix and settling on An three circular, clearing development to something like 60 seconds, will separate the membranes starting with the cervix. This system camwood make uncomfortable and might encounter a little sum from claiming blood- stained mucous Furthermore period sort agony subsequently. [4]. Prostaglandins are pills that assistance actuate Labor by swaying the cervix on mollify Also abbreviate (ripen). Prostaglandins (PGE2 = dinoprostone) may be the favored operators to cervical aging. It will be normally provided for intra vaginally under those posterior fornix. Those gel structure is Consumed great. Same time those tablet types need aid less demanding on uproot if hyperstimulation happens (5-7\%). Vaginal prostaglandins (3mg tablets, $2 \mathrm{mg}$ gel) expansion vaginal conveyance rates inside $24 \mathrm{hrs}$ with no expansion for agent conveyance rates. [5]. Prostaglandins (PG E1= Misoprostol) seems to be Concerning illustration viable an incitement agenize in the third trimester. It need been utilized within doses extending from $50 \mu \mathrm{g}$ (administered 4-hourly for every vagina should a most extreme of five doses) to $100 \mu \mathrm{g}$ (as single alternately repeatable doses), Furthermore in spite of the fact that the incitement with conveyance interim may be decreased for expanding doses, this may be frequently all the at those expanded danger about uterine hypertonus. Oral doses show up with a chance to be safer over vaginal doses, Be that there may be still not sufficient information with make wellbeing. [6]. Clearing of the membranes during full term is connected with a shorter pregnancy What's more lessens those amount of pregnancies proceeding Past 41 What's more 42 weeks. Particular case for every 8 ladies who bring film clearing will stay away 
from formal incitement from claiming labor, yet the cesarean conveyance danger is not essentially lessened then afterward film clearing. [7]. This ponder meant will evaluate those impact for membranes clearing for incitement from claiming work at full-term from 39 with 40 weeks.

\section{Patients and methods}

This study was randomized controlled study.

Study settings: Benha University Hospital and Benha Teaching Hospital .

\subsection{Ethical considerations}

The study was approved by the Ethics Committee of the Obstetrics and Gynecology department \& the Faculty of Medicine, Benha University in the period from $1 / 11 / 2018$ to $30 / 9 / 2019$. Informed consent was obtained from each participant.

\subsection{Study population}

One handrad and twenty Cases were recruited among those attending Obstetrics \& Gynecology Departments of both hospitals need for induction of labour at full term.

Participants were randomly scheduled into two groups: Group A membrane sweeping (60 patients) that were subdivided into A1: Primigravida (30 patients) and A2: Multigravida (30 patients). Group B no membrane sweeping (60 patients) subdivided into B1 Primigravida (30 patients) and B2 Multigravida (30 patients) with $80 \%$ power and $21.0 \pm 010.0$ using $\frac{z^{2} \times S D^{2}}{E^{2}}$ and sample size calculation program.

\subsection{The inclusion criteria}

1. Full term $39^{\frac{1}{7}}$ to $40^{\frac{6}{7}}$ weeks

2. Singleton fetus

3. Cephalic presentation

4. Intact membranes

5. Reassuring fetal status by cardiotocography.

6. Favorable cervix for induction according to bishop score.

\subsection{The exclusion criteria}

1. Medical problems that can affect fetal well-being.

2. Antepartum hemorrhage.

3. Known gross fetal anomalies.

4. Contraindications to vaginal delivery (e.g., placenta previae and breech presentation).

5. Patients with previous uterine scar.

\section{Methodology}

1. A point by point history.

2. Schedule antenatal investigations were reviewed and requested if not completed When.

3. Examination. (General, obstetrics Furthermore neighborhood examination).

4. Trans-abdominal U/S. Might have been accomplished for all patients to affirm gestational agdistis Also other helps as CTG and conceivable fetal doppler indices At shown.

5. Diocesan score What's more Tvs were accomplished for the sum ceases over both bunches.

Cases over aggregation a were under went film clearing during full term from 39 will 40 weeks, sit tight to 72 hours for spontaneous onset for labour, though not happened formal incitement from claiming work began by utilizing intra vaginal misoprostol $25 \mu \mathrm{g}$ 4-hourly on a most extreme 4 doses. Film clearing include under went a vaginal examination et cetera putting An finger inside the cervix What's more settling on three boundary clearing developments to differentiate the membranes from those cervix. This obliges that those cervical os concedes An finger, What's more includes digitally dividing the membranes starting with those cervix. The impact of film clearing with respect to work incitement and the mode about conveyance were assessed. Pelvic examination were performed will survey the status of the cervix Toward diocesan scoring. Transvaginal ultrasongraphic estimation of the cervical period were performed should see those impact for film clearing then afterward $72 \mathrm{~h}$ later.

Situations over bunch $b$ who met those Incorporation criteria were under went incitement from claiming work Eventually Tom's perusing intra vaginal misoprostol $25 \mu \mathrm{g}$ 4-hourly with An greatest 4 doses.

\section{Measurable dissection}

Those information were coded, entered and transformed ahead PC utilizing SPSS (version 23). Those comes about were spoken to Previously, plain and diagrammatic types then translated. Mean, standard deviation, range, frequency, Also rate were use as spellbinding facts. The Emulating test might have been done: Chi-Square test $\mathrm{X}^{2}$ might have been used to test those Acquaintanceship variables for unmitigated information. Student's t-test might have been used to survey the measurable noteworthiness of the Contrast between two number implies in An investigation directing, including autonomous specimens. $\mathrm{P}$ worth might have been recognized critical as the following: $\mathrm{p}>0$. 05: Non critical. $\mathrm{P} \leq 0$. 05: critical. 5 .

\section{Results}

Table (1)There was no statistically significant difference between Group A and Group B regarding Age

Table (2)There was no statistically significant difference between Group A1, Group A2, Group B1 and Group B2 regarding GA

Table (3)There was no statistically significant difference between Group A1, Group A2, Group B1 and Group B2 regarding Mode of delivery.

Table (4)There was no statistically significant difference between Group A1, Group A2, Group B1 and Group B2 regarding Bishop Score. 
There was no statistically significant difference between Group A1, Group A2, Group B1 and Group Table (5)B2 regarding Cervical length.

Table (6) There was statistically significant difference between Group A and Group B regarding Partogram special signs.

There was no statistically significant difference between Group A1, Group A2, Group B1 and Table (7)Group B2 regarding Side effects.

There was no statistically significant difference between Group A1, Group A2, Group B1 and Table (9)Group B2 regarding APGAR score at 1 minute and 5 minutes and NICU admission. Table (8)
There was no statistically significant difference between Group A1, Group A2, Group B1 and Group $\mathrm{B} 2$ regarding $\mathrm{PPH}$.

Table (10)There was statistically significant decrease in Interrval between Maneuver /Labour among Group A1 than Group B1 There was statistically significant decrease in Interrval between Table(11)Maneuver /Labour among Group A2 than Group B2

Success rate of membrane sweeping among group A was $81.7 \%$. There was no statistically significant difference between Group A1 and Group A2 regarding success rate of membrane sweeping.

Table (1) Comparison between Group A and Group B regarding Age.

\begin{tabular}{cccccc}
\hline & & $\begin{array}{c}\text { Group A } \\
(\text { No. }=\text { 60) }\end{array}$ & $\begin{array}{c}\text { Group B } \\
(\text { No. }=60)\end{array}$ & t. test & P. value \\
\hline $\begin{array}{c}\text { Age } \\
(\text { years })\end{array}$ & Rang & $17-35$ & $17-43$ & $-.752-$ & 0.453 \\
\hline
\end{tabular}

Table (2) Comparison between Group A1, Group A2, Group B1 and Group B2 regarding GA

\begin{tabular}{lcccr}
\hline GA & Group A1 $($ No. $=$ & Group A2 $($ No. $=$ & Group B1 $($ No. $=$ & Group B2 $($ No. $=$ \\
(Wks) & 30) & 30) & 30) & 30) \\
\hline Rang & $39.14-40.14$ & $39.14-40.29$ & $39.14-40.29$ & $39.14-40.29$ \\
Mean \pm SD & $39.7 \pm 0.43$ & $39.4 \pm 0.36$ & $39.6 \pm 0.47$ & $39.3 \pm 0.43$ \\
F. test & & \multicolumn{2}{c}{1.3} \\
P. value & \multicolumn{3}{c}{0.26} \\
\hline
\end{tabular}

Table (3) Comparison between Group A1, Group A2, Group B1 and Group B2 regarding Mode of delivery

\begin{tabular}{|c|c|c|c|c|c|c|c|c|}
\hline & & & $\begin{array}{l}\text { Group A1 } \\
(\text { No.= 30) }\end{array}$ & $\begin{array}{c}\text { Group A2 } \\
(\text { No.= 30) }\end{array}$ & $\begin{array}{c}\text { Group B1 } \\
(\text { No. }=30)\end{array}$ & $\begin{array}{l}\text { Group B2 } \\
(\text { No. }=30)\end{array}$ & $\mathrm{X}^{2}$ & P. value \\
\hline \multirow{4}{*}{$\begin{array}{l}\text { Mode of } \\
\text { delivery }\end{array}$} & LSC & No. & 4 & 1 & 6 & 5 & \multirow{4}{*}{4.038} & \multirow{4}{*}{0.257} \\
\hline & $\mathbf{S}$ & $\%$ & $13.3 \%$ & $3.3 \%$ & $20.0 \%$ & $16.7 \%$ & & \\
\hline & & No. & 26 & 29 & 24 & 25 & & \\
\hline & NVD & $\%$ & $86.7 \%$ & $96.7 \%$ & $80.0 \%$ & $83.3 \%$ & & \\
\hline
\end{tabular}

Table (4) Comparison between Group A1, Group A2, Group B1 and Group B2 regarding Bishop Score

\begin{tabular}{lcccc}
\hline Bishop Score & $\begin{array}{c}\text { Group A1 }(\text { No. }= \\
\text { 30) }\end{array}$ & Group A2 $($ No.= 30) & $\begin{array}{c}\text { Group B1 }(\text { No. }= \\
\text { 30) }\end{array}$ & $\begin{array}{c}\text { Group B2 }(\text { No. }= \\
\text { 30) }\end{array}$ \\
\hline Rang & $5-7$ & $3-7$ & $4-6$ & $4-6$ \\
Mean \pm SD & $5.20 \pm 0.997$ & $5.17 \pm 0.747$ & $4.70 \pm 0.79$ & $5.3 \pm 0.73$ \\
F. test & & 2.34 & & \\
P. value & & & & \\
\hline
\end{tabular}

Table (5) Comparison between Group A1, Group A2, Group B1 and Group B2 regarding Cervical length by TVU

\begin{tabular}{lcccc}
\hline Cervical length by & Group A1 (No. $=$ & Group A2 & Group B1 (No.= & Group B2 (No.= \\
TVU & 30) & (No.= 30) & 30) & 30) \\
\hline Rang & $24-32$ & $22-32$ & $20-32$ & $23-32$ \\
Mean \pm SD & $28.90 \pm 2.249$ & $28.77 \pm 2.89$ & $28.4 \pm 2.95$ & $28.3 \pm 2.6$ \\
F. test & \multicolumn{2}{c}{11.126} \\
P. value & \multicolumn{2}{c}{0.09} \\
\hline
\end{tabular}


Table (6) Comparison between Group A1, Group A2, Group B1 and Group B2 regarding Partogram special signs

\begin{tabular}{|c|c|c|c|c|c|c|c|c|}
\hline & & & $\begin{array}{c}\text { Group A1 } \\
(\text { No.= 30) }\end{array}$ & $\begin{array}{c}\text { Group A2 } \\
(\text { No.= 30) }\end{array}$ & & $\begin{array}{c}\text { Group B2 } \\
(\text { No.= 30) }\end{array}$ & $\mathbf{X} 2$ & $\begin{array}{c}\text { P. } \\
\text { value }\end{array}$ \\
\hline \multirow{14}{*}{$\begin{array}{l}\text { Partogram } \\
\text { special } \\
\text { signs }\end{array}$} & No & No. & 26 & 29 & 24 & 25 & \multirow{14}{*}{37.3} & \multirow{14}{*}{0.005} \\
\hline & & $\%$ & $86.7 \%$ & $96.7 \%$ & $80.0 \%$ & $83.3 \%$ & & \\
\hline & Arrest of 2nd & No. & 2 & 0 & 0 & 0 & & \\
\hline & stage (OP) & $\%$ & $6.7 \%$ & $.0 \%$ & $.0 \%$ & $.0 \%$ & & \\
\hline & \multirow{4}{*}{$\begin{array}{c}\text { Arrest of head } \\
\text { descent } \\
\text { Fetal distress }\end{array}$} & No. & 0 & 0 & 3 & 0 & & \\
\hline & & $\%$ & $.0 \%$ & $.0 \%$ & $10.0 \%$ & $.0 \%$ & & \\
\hline & & No. & 0 & 1 & 3 & 1 & & \\
\hline & & $\%$ & $.0 \%$ & $3.3 \%$ & $10.0 \%$ & $3.3 \%$ & & \\
\hline & Fetal distress & No. & 2 & 0 & 0 & 0 & & \\
\hline & $\begin{array}{c}\text { (thick } \\
\text { meconium) }\end{array}$ & $\%$ & $6.7 \%$ & $.0 \%$ & $.0 \%$ & $.0 \%$ & & \\
\hline & Fetal distress & No. & 0 & 0 & 0 & 2 & & \\
\hline & $\begin{array}{c}\text { (thin } \\
\text { meconium) }\end{array}$ & $\%$ & $.0 \%$ & $.0 \%$ & $.0 \%$ & $6.7 \%$ & & \\
\hline & Obstructed & No. & 0 & 0 & 0 & 2 & & \\
\hline & labour & $\%$ & $.0 \%$ & $.0 \%$ & $.0 \%$ & $6.7 \%$ & & \\
\hline
\end{tabular}

Table (7) Comparison between Group A and Group B regarding side effects and patients satisfaction about the procedure.

\begin{tabular}{lcccc}
\hline $\begin{array}{l}\text { Side effects and patients } \\
\text { satisfaction about the } \\
\text { procedure }\end{array}$ & $\begin{array}{c}\text { Group A1 } \\
(\text { No.= 30) }\end{array}$ & $\begin{array}{c}\text { Group A2 } \\
(\text { No.= 30) }\end{array}$ & $\begin{array}{c}\text { Group B1 } \\
(\text { No.= 30) }\end{array}$ & $\begin{array}{c}\text { Group B2 } \\
(\text { No.= 30) }\end{array}$ \\
\hline $\begin{array}{l}\text { No side effects } \\
\text { Side effects }\end{array}$ & $50.0 \%$ & $50.0 \%$ & $100.0 \%$ & $100.0 \%$ \\
$\begin{array}{l}\text { Painful procedure } \\
\text { Minimal spotting }\end{array}$ & $30.0 \%$ & $30.0 \%$ & $0.0 \%$ & $0.0 \%$ \\
$\begin{array}{l}\text { Satisfaction about the } \\
\text { procedure }\end{array}$ & $20.0 \%$ & $20.0 \%$ & $0.0 \%$ & $0.0 \%$ \\
\hline
\end{tabular}

Table (8) Comparison between Group A and Group B regarding Apgar score at 1 and 5 minutes and NICU admission.

\begin{tabular}{|c|c|c|c|c|c|c|c|}
\hline Neonatal variable & & $\begin{array}{c}\text { Group A1 } \\
(\text { No.= 30) }\end{array}$ & $\begin{array}{c}\text { Group A2 } \\
(\text { No.= 30) }\end{array}$ & $\begin{array}{c}\text { Group B1 } \\
(\text { No.= 30) }\end{array}$ & $\begin{array}{c}\text { Group B2 } \\
(\text { No.= 30) }\end{array}$ & $\mathbf{X} 2$ & $\begin{array}{c}\text { P. } \\
\text { value }\end{array}$ \\
\hline $\begin{array}{l}\text { Apgar score at } 1 \\
\text { minute }\end{array}$ & Mean \pm SD & $8.2 \pm 0.1$ & $8.1 \pm 0.4$ & $8.5 \pm 0.03$ & $8.6 \pm 0.05$ & $\begin{array}{c}\text { f test } \\
1.4\end{array}$ & 0.81 \\
\hline $\begin{array}{l}\text { Apgar score at } 5 \\
\text { minutes }\end{array}$ & Mean \pm SD & $9.1 \pm 0.3$ & $9.05 \pm 0.03$ & $9.2 \pm 0.07$ & $9.08 \pm 0.1$ & $\begin{array}{l}\mathrm{f} \text { test } \\
2.01\end{array}$ & 0.93 \\
\hline NICU admission & $\begin{array}{c}\text { No } \\
\text { admission }\end{array}$ & $\begin{array}{c}30 \\
100.0 \%\end{array}$ & $\begin{array}{c}30 \\
100.0 \%\end{array}$ & $\begin{array}{c}30 \\
100.0 \%\end{array}$ & $\begin{array}{c}30 \\
100.0 \%\end{array}$ & 0 & 1 \\
\hline
\end{tabular}

Table (9) Comparison between Group A and Group B regarding PPH.

\begin{tabular}{lcccccc}
\hline PPH & $\begin{array}{c}\text { Group A1 } \\
(\text { No.= 30) }\end{array}$ & $\begin{array}{c}\text { Group A2 } \\
(\text { No.= 30) }\end{array}$ & $\begin{array}{c}\text { Group B1 } \\
(\text { No.= 30) }\end{array}$ & $\begin{array}{c}\text { Group B2 } \\
(\text { No.= 30) }\end{array}$ & X2 & $\begin{array}{c}\text { P. } \\
\text { value }\end{array}$ \\
\hline \multirow{2}{*}{ No PPH } & 30 & 30 & 30 & 30 & 0 & 1 \\
\hline
\end{tabular}

Table (10) Comparison between Group A1, Group A2, Group B1 and Group B2 regarding Interrval between Maneuver /Labour

\begin{tabular}{lcccc}
\hline $\begin{array}{l}\text { Interrval between } \\
\text { Maneuver } / \text { Labour }\end{array}$ & $\begin{array}{c}\text { Group A1 } \\
(\text { No.= 30) }\end{array}$ & $\begin{array}{c}\text { Group A2 } \\
\text { (No.= 30) }\end{array}$ & $\begin{array}{c}\text { Group B1 } \\
\text { (No.= 30) }\end{array}$ & $\begin{array}{c}\text { Group B2 (No.= } \\
\text { 30) }\end{array}$ \\
\hline Rang & $9-18$ & $3-18$ & $8-24$ & $1-24$ \\
Mean \pm SD & $14.87 \pm 3.17$ & $9.07 \pm 3.47$ & $15 \pm 5.913$ & $11.37 \pm 3.19$
\end{tabular}


Table (10) Continue

\begin{tabular}{lc}
\hline f. test & 4.84 \\
P. value & 0.003 \\
P & $\mathrm{P} 1=0.04$ \\
\end{tabular}

$$
\text { P1 = between Group A1 and Group B1 }
$$

P2 = between Group A2 and Group B2

Table (11) Success rate of membrane sweeping among group A.

\begin{tabular}{lcccc}
\hline \multicolumn{2}{l}{ Success rate of membrane sweeping } & $\begin{array}{c}\text { Group A } \\
\text { (No.= 60) }\end{array}$ & $\mathbf{X}^{\mathbf{2}}$ & P. value \\
\hline Group A1 & Successed & $23(76.7 \%)$ & & \\
(No.= 30) & Not Successed & $7(23.3 \%)$ & 1.02 & 0.31 \\
Group A2 & Successed & $76(86.7 \%)$ & & \\
(No.= 30) & Not Successed & $4(13.3 \%)$ & \\
Total Group A & Successed & $49(81.7 \%)$ & \\
(No.= 60) & Not Successed & $11(18.3 \%)$ & \\
\hline
\end{tabular}

\section{Discussion}

This ponder might have been randomized regulated consider which led during Benha college doctor's facility Also Benha educating help doctor's facility. This investigation might have been conveyed once 120 situations that recruited around the individuals going to obstetrics \& Gynecology divisions about both healing facilities to requiring incitement from claiming Labor at full term. Members were haphazardly planned under two groups: bunch a film clearing (60 patients) subdivided under A1: Primigravida (30 patients) What's more A2: Multigravida (30 patients). Assembly b no film clearing (60 patients) subdivided under B1 Primigravida (30 patients) Also B2 Multigravida (30 patients).

This ponder indicated that, there were no statistically critical distinction between gathering a and one assembly $\mathrm{b}$ viewing agdistis (22. 9yr vs. 23. $7 \mathrm{yr} \mathrm{p}$ $=0.45)$.

This investigation indicated that, there might have been no statistically huge Contrast the middle of one assembly An What's more assembly b in regards ga. (39. 6wk vs. 39. $5 \mathrm{wk} \mathrm{p}=0.19$ ).

This agrees with Yildirim et al. , [7] who meant with assess the viability from claiming film clearing during start for work incitement in low-risk patients at haul pregnancy (38-40 gestational weeks). They discovered that, there might have been no statistically critical distinction the middle of An clearing of the membranes assembly Also a no clearing control bunch viewing ga (39wk (38. 2-39. 8) vs. 39wk (38. 2-39. 5) $\mathrm{p}=0.14)$.

This contemplate demonstrated that there might have been no statistically huge distinction between bunch A1, aggregation A2, aggregation B1 Also aggregation B2 viewing mode about conveyance.

In the exhibit study, there might have been no statistically noteworthy Contrast between aggregation A1, bunch A2, gathering B1 Furthermore aggregation $\mathrm{B} 2$ in regards diocesan score Also cervical period.
This agrees for Yildirim et al. , [7] who found that, the diocesan score didn't contrast essentially the middle of the gatherings. $(1(1-2)$ v. $1(1-2), p=0.93)$.

This study demonstrated that there might have been statistically noteworthy Contrast the middle of bunch a Furthermore aggregation $\mathrm{b}$ in regards Partogram uncommon indications

There was no side effects reported in Group B1 and Group B2 compared with 50\% of the patients in Group A1 and Group A2.

$30 \%$ of the patients in Group A1 and Group A2 reported that the procedure was uncomfortable and/or painful and $20 \%$ had minimal spotting after the procedure. $60 \%$ of the women in the Group A1 and Group A2 felt satisfaction about the procedure, compared with $90 \%$ of the women in the Group B1 and Group B2.

News person unfriendly impacts from claiming misoprostol, for example, such that vomiting, diarrhoea, tachysystole or hyperstimulation, were not recorded in this contemplate.

There may be no proof that clearing the membranes builds those hazard of maternal Also neonatal unfriendly conclusions. As proposed in the metaanalysis. [4]. This agrees for [7] who found that, there might have been no statistically critical Contrast between those bunches for maternal difficulties. (4. $4 \%$ v. $1.7 \%, \mathrm{p}=0.28)$.

However, $20 \%$ of the patients in the ms assembly accounted that the system might have been uncomfortable or painful, comparative will sooner reports, [8] Also 9\% required insignificant spotting following those procedure, which hence subsided. No the event for break of the membranes alternately antepartum discharge might have been recorded. On an inclination scale, $43 \%$ of the ladies in the ms aggregation felt sure over the intervention, compared with $92 \%$ of the ladies in the OM assembly who might consent to utilize of the pill in an additional post-term pregnancy.

An real constraint for randomized trial is that they would rarely extensive sufficient on consider 
extraordinary unfriendly impacts. No destructive unfriendly impacts of ms need been news person over past investigations. [4]. In the available study, there might have been no statistically huge distinction the middle of assembly An and one assembly b viewing apgar score toward $1 \mathrm{~min}$ and $5 \mathrm{mins}$ and nicu confirmation. $(0 \%$ v. $0 \%, \mathrm{p}=1$.

This agrees for [9] who discovered there were no contrasts in the frequency about nicu confirmation between those two Assemblies. (1. 3\% vs. 5\%, p $=0$. 184).

This agrees likewise with [7] who found that, there might have been no statistically critical Contrast between the aggregations done fetal difficulties. (5. 6\% vs. $3 \%, \mathrm{p}=0.23)$.

This agrees also with [10] who found that, overall, require to nicu confirmation were comparative Also tantamount in the two gatherings. ( $4 \%$ vs. $4 \%, \mathrm{p}=0$. 93).

In the introduce study, there might have been no statistically huge Contrast between assembly a Furthermore assembly b in regards to PPH. (0\% v. $0 \%$, $\mathrm{p}=1)$.

This agrees for [9] who discovered there were no contrasts in the frequency from claiming PPH between the two Assemblies. (1.3\% v. 1. 3\%, p=0.75).

This contemplate indicated that, there might have been statistically huge diminishing done Interrval between manet /Labour Around assembly A1 over aggregation B1. There might have been statistically critical diminish Previously, Interrval the middle of manet /Labour Around bunch A2 over aggregation B2).

This agrees for [8] who indicated that there might have been a noteworthy distinction in the average number for days will conveyance between the gatherings. Clearing diminished the chance between randomisation and conveyance Eventually Tom's perusing 4 times. Those distinction in time might have been reflected in the event about spontaneous onset for work in front of 41 weeks.

This study indicated that, victory rate about film clearing Around aggregation a might have been 81 . $7 \%$. It also indicated that there might have been no statistically huge Contrast between gathering A1 What's more bunch $\mathrm{A} 2$ in regards prosperity rate from claiming film clearing (76. $7 \%$ v. $86.7 \%)$.

This agrees with [7] who pointed should assess those viability from claiming film clearing at start for work incitement Previously, low-risk patients In haul pregnancy (38-40 gestational weeks). They found that, those mode about conveyance didn't contrast fundamentally between the Assemblies. (87. $87 \%$ v. $80 \%)$.

This agrees Additionally with [10] who meant on evaluate the viability of the two outpatient forms about single-dose $50 \mu \mathrm{g}$ oral misoprostol (OM) Also film clearing (MS) on the result of Labor incitement and the likelihood from claiming lessening those requirement to healing center confirmation to cervical ripening/labour incitement On uncomplicated postterm singleton pregnancies at a tertiary wellbeing foundation Previously, south-western nigeria. They found the proportions from claiming vaginal conveyances were comparative in the two groups, ( 83 . $3 \%$ v. $86.7 \%$ ).

A few investigations have indicated that fewer ladies inevitably necessity incitement to pregnancy Past 41 weeks Assuming that film clearing will be performed antenatally. [11]. It need also been indicated on increment the spontaneous vaginal conveyance rate The point when used at those the long haul from claiming formal incitement. [12]. Hypothetically it need been contended that film clearing might be additional viable to multiparous over nulliparous patients. This supposition need been debated by de Miranda. , [8] Also Might a chance to be substantiated Eventually Tom's perusing our investigation for which the triumph rate clinched alongside primigravida 76 . $7 \%$ versus $86.7 \%$ in multigravida.

\section{Conclusion}

Sweeping of membranes is a safe method for reducing the length of term pregnancy and the incidence of prolonged gestation in a low risk population. There is no evidence that sweeping the membranes increases the risk of maternal and neonatal adverse outcomes.

\section{References}

[1] J.P.Vogel,A.P.Betrán,N.Vindevoghel, J.P.Souza, M.R.Torloni, J.Zhang on behalf of the WHO Multi-Country Survey on Maternal and Newborn Health Research Network. Use of the Robson classification to assesscaesarean section trends in 21 countries: a secondary analysis of two WHO multi-country surveys. Lancet Global Health. Vol..3(5), PP. e260-70. ,2015.

[2]C.G.Victora,F.C.Barros: Beware: un necessary caesarean sections may be hazardous. Lancet.Vol. 367(9525), PP. 1796-7,2006.

[3]WHO recommendations for induction of labour. World Health Organization: Geneva, 2011.

[4]M.Boulvain, C.M.Stan, O.Irion. Membrane sweeping for induction of labour. Cochrane Database of Systematic Reviews CD000 451.2009

[5] NICE Induction of Labour. Clinical Guideline 70. London: National Institute for Health and Clinical Excellence, 2011.

[6] Z.Alfirevic, A.Weeks. Oral misoprostol for induction of labour. Cochrane Database Syst Rev,Vol.2, PP. CD001338,2008.

[7] G.YILDIRIM, GU K“ NGO“ RDU N. Membrane sweeping to induce labor in low-risk patients at term pregnancy: A randomised controlled trial. The Journal of Maternal-Fetal and Neonatal Medicine, July,Vol..23(7), PP. 681-687,2010.

[8] E.De Miranda, J.Van der Bom, G.Bonsel, O.Bleker, F.Rosendaal. Membrane sweeping and prevention of post-term pregnancy in low-risk pregnancies: a 
randomised controlled trial. BJOG, Vol. 113, PP.402-408,2006.

[9] Zamzami T, Al Senani N. The efficacy of membrane sweeping at term and effect on the duration of pregnancy: a randomized controlled trial. Journal of Clinical Gynecology and Obstetrics 3:30-34.2010

[10] A.O.ADENIJI, S.E.AKINOLA A comparison of orally administered misoprostol and membrane sweeping for labour induction in uncomplicated, singleton post-term pregnancies. South African
Journal of Obstetrics and Gynaecology, [S.1.] Vol. 19(1), PP. 4-7, dec.. ISSN 2305-8862,2012.

[11] E.L.Mozurkewich, J.L.Chilimigras, D.R.Berman, U.C.Perni, V.C.Romero, V.J.King, K.L.Keeton. Methods of induction of labour: a systematic review. BMC Pregnancy Childbirth. Vol. 11, pp. 84,2011.

[12] P.Tan, R.Jacon, S.Omar. Membrane sweeping at initiation of formal labor induction: a randomized controlled trial. Obstet Gynecol.Vol. 107(3), PP.569-577, 2006. 